\title{
Cystic lesion of the fourth ventricle Role of CISS
}

Figure $1 \quad C T$ and MRI
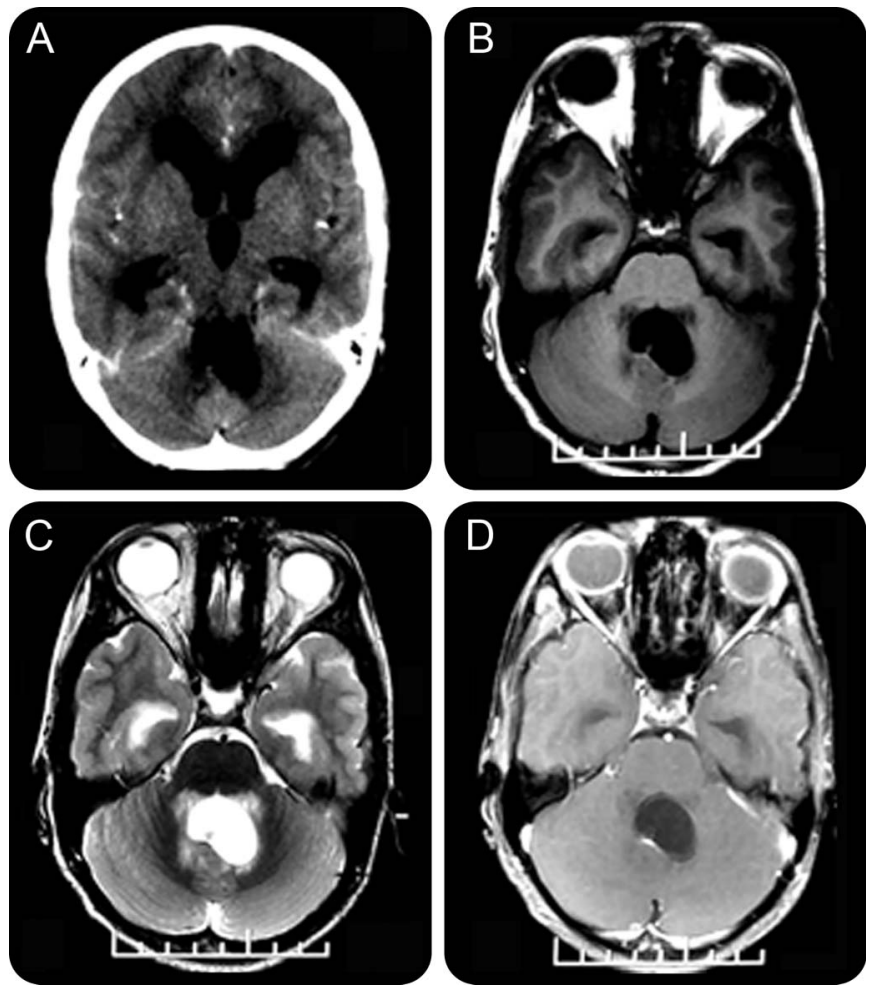

(A) Contrast-enhanced CT and (B) T1-weighted, (C) T2-weighted, and (D) postcontrast T1-weighted MRI brain show a dilated and distorted fourth ventricle with a nodule.

A 13-year-old boy presented with headache of 1 month and vomiting for 10 days. Salient examination findings were left lateral rectus paresis and papilledema. A contrast-enhanced CT followed by MRI brain revealed an illdefined fourth ventricular cyst with communicating hydrocephalus (figure 1). Subsequently, a constructive interference in steady state (CISS) sequence revealed a fourth ventricular cysticercus (figure 2).

Intraventricular neurocysticercus may be missed on conventional CT and MRI. ${ }^{1}$ A distinctly visible scolex and CISS sequence, with its higher contrast-to-noise ratio and accentuation of $\mathrm{T} 2$ value between the cyst and CSF, rules out malignant radiologic differentials. ${ }^{2}$

Lokesh Saini, MD, Biswaroop Chakrabarty, DM, Atin Kumar, MD, Sheffali Gulati, MD

From the All India Institute of Medical Sciences, New Delhi, India.

Author contributions: Dr. Saini and Dr. Chakrabarty worked up the patient and prepared the manuscript under the guidance of Dr. Gulati. Dr. Kumar provided the radiologic inputs.

Study funding: No targeted funding reported.

Disclosure: The authors report no disclosures relevant to the manuscript. Go to Neurology.org for full disclosures.

Correspondence to Dr. Gulati: sheffaligulati@gmail.com

1. Khandelwal S, Sakhi P, Sharma GL, Saxena UD. Intraventricular cysticercosis. Ind J Radiol Imag 2002;12:329-332.

2. Govindappa SS, Narayanan JP, Krishnamoorthy VM, Shastry CH, Balasubramaniam A, Krishna SS. Improved detection of intraventricular cysticercal cysts with the use of three-dimensional constructive interference in steady state MR sequences. Am J Neuroradiol 2000;21:679-684. 
Figure 2 Constructive interference in steady state sequence

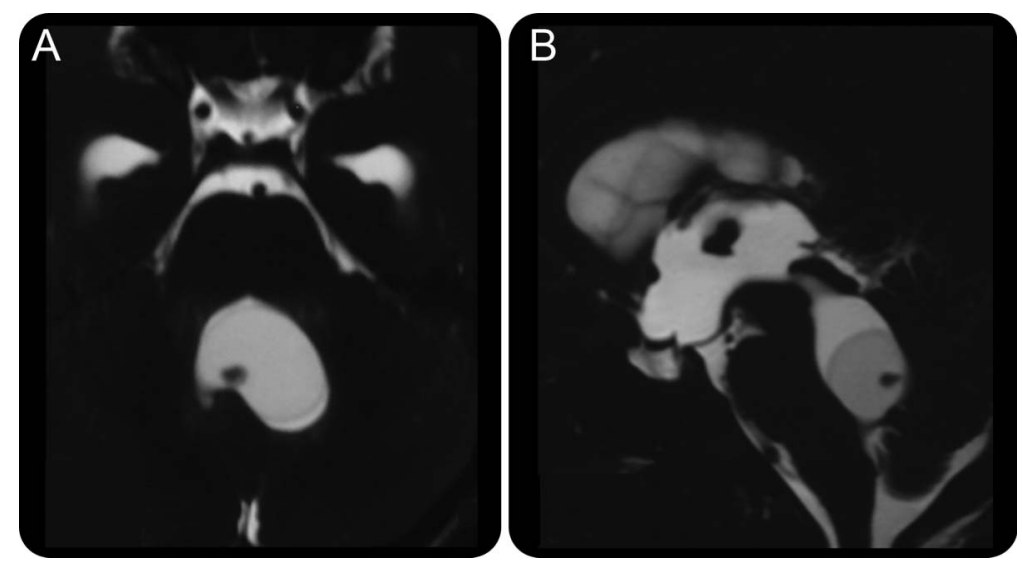

(A, B) Fourth ventricular cysticercus (mural nodule present). 


\title{
Neurology
}

\author{
Cystic lesion of the fourth ventricle: Role of CISS \\ Lokesh Saini, Biswaroop Chakrabarty, Atin Kumar, et al. \\ Neurology 2015;85;1181-1182 \\ DOI 10.1212/WNL.0000000000001981
}

This information is current as of September 28, 2015

\section{Updated Information \&} Services

\section{References}

Subspecialty Collections

\section{Permissions \& Licensing}

Reprints including high resolution figures, can be found at: http://n.neurology.org/content/85/13/1181.full

This article cites 2 articles, 1 of which you can access for free at: http://n.neurology.org/content/85/13/1181.full\#ref-list-1

This article, along with others on similar topics, appears in the following collection(s):

All Imaging

http://n.neurology.org/cgi/collection/all_imaging

CT

http://n.neurology.org/cgi/collection/ct

Hydrocephalus

http://n.neurology.org/cgi/collection/hydrocephalus

\section{MRI}

http://n.neurology.org/cgi/collection/mri

Parasitic infections

http://n.neurology.org/cgi/collection/parasitic_infections

Information about reproducing this article in parts (figures,tables) or in its entirety can be found online at:

http://www.neurology.org/about/about_the_journal\#permissions

Information about ordering reprints can be found online:

http://n.neurology.org/subscribers/advertise

Neurology ${ }^{\circledR}$ is the official journal of the American Academy of Neurology. Published continuously since 1951, it is now a weekly with 48 issues per year. Copyright @ 2015 American Academy of Neurology. All rights reserved. Print ISSN: 0028-3878. Online ISSN: 1526-632X.

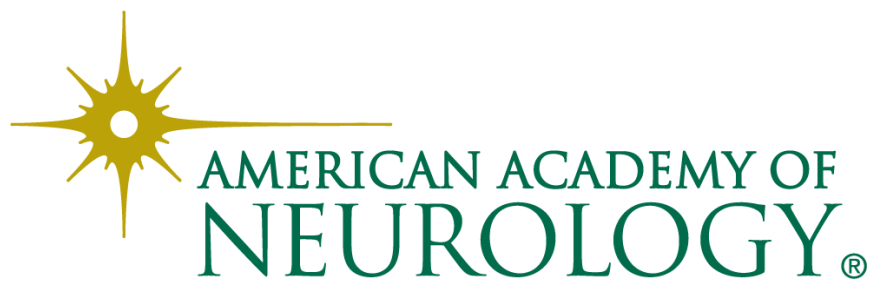

